\title{
Anti-Helicobacter pylori Activity of New Synthetic Fenitoin Derivatives
}

\section{Geisa Helmold Aspesi ${ }^{a *}$, Ana Lúcia Alves de Arruda ${ }^{a}$ and Carlos Kleber Z. Andrade}

a Departamento de Ciências Biológicas e da Saúde, Universidade Católica Dom Bosco (UCDB), Avenida Tamandaré 6000, Jardim Seminário, C. P. 79117-900, Campo Grande, MS, Brasil.

b Laboratório de Química Metodológica e Orgânica Sintética - LaQMOS - Instituto de Química, Universidade de Brasília, Campus Darcy Ribeiro, Asa Norte, C. P. 70910-970 Brasília, DF, Brasil.

\section{*ghaspesi@gmail.com}

Keywords: Synthesis, Fenitoin, Helicobacter pylori

\section{INTRODUCTION}

Many hidantoin derivatives have pharmacological activities (anticonvulsant ${ }^{1}$, antifungic ${ }^{2}$, antibacterial ${ }^{2}$ and antiparasitic ${ }^{2}$ ), related to the substituent in positions 3 or 5 of the imidazolidinic-like ring.

In this work, several 3-substituted imidazolidinic-like compounds were synthesized from fenitoin, aiming at potential new drugs presenting more selectivity, security, less toxicity and lower cost on the treatment of ulcer, caused by Helicobacter pylori.

\section{RESULTS AND DISCUSSION}

Synthetic fenitoin 1, after being converted to the $N$ alkylated compound 2 (29\%), from (Z)-4-chloro-2butenyl acetate ${ }^{3}$ and $\mathrm{DBU}$ in $\mathrm{CH}_{2} \mathrm{Cl}_{2}$, afforded by subsequent hydrolysis in aqueous $\mathrm{HCl}^{3}$ the respective alcohol 3 in 68\% yield (Scheme 1). On another route, fenitoin 1 was $N$-alkylated with 1,3dibromo-propane ${ }^{4}$ and the resulting halogenated intermediate $4(69 \%)$, after treatment with sodium azide, yielded the corresponding azide 5 (92\%). Using Click chemistry, ${ }^{5}$ the triazol rings 6 and 7 were obtained in $83 \%$ and $38 \%$ yield, respectively. The allylic alcohol in 7 was oxidized with manganese dioxide $^{6}$ to give the corresponding ketone 8 (92\%).

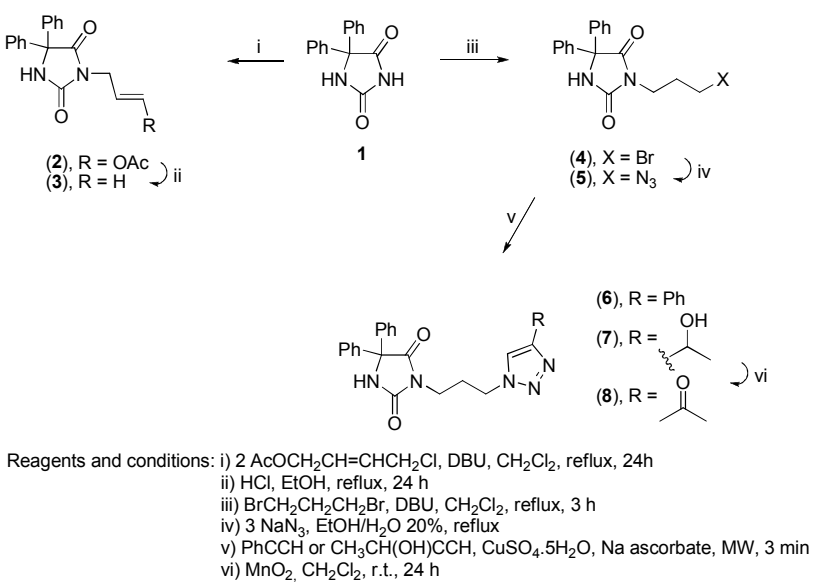

Scheme 1. New derivatives of hydantoin synthesis
The activity against Helicobacter pylori (ATTC) was evaluated by disc diffusion assay. Sterile 0,6 mm diameter filter paper discs were impregnated with 20 $\mu \mathrm{L}$ of the samples $(100 \mathrm{mg} / \mathrm{mL})$ and placed in Müller Hinton agar. Commercially discs with amoxicillin and DMSO were used as positive and negative controls, respectively. The discs with the samples, positive and negative controls, were distributed by Petri plates and incubated at $37^{\circ} \mathrm{C}$ for $24 \mathrm{~h}$. The results, illustrated in Table 1, were recorded by measuring the growth inhibition zones surrounding the disc. All tests were carried out in triplicate.

Table 1. Evaluation of Anti-Helicobacter pylori activity of fenitoin derivatives and standard controls

\begin{tabular}{|c|l|l|l|l|l|l|l|l|l|}
\hline $\mathbf{S}$ & $\mathbf{2}$ & $\mathbf{3}$ & $\mathbf{4}$ & $\mathbf{5}$ & $\mathbf{6}$ & $\mathbf{7}$ & $\mathbf{8}$ & PC & $\mathbf{C}-$ \\
\hline $\mathbf{I Z}$ & 8,3 & 8,0 & 8,0 & 9,0 & 8,0 & 7,6 & 8,6 & 16,0 & - \\
& & & & & & & & & \\
\hline
\end{tabular}
control; C-: Negative control (DMSO)

\section{CONCLUSION}

All compounds tested were active against Helicobacter pylori indicating that these new derivatives are promising drugs and shall be more carefully studied.

\section{ACKNOWLEDGEMENTS}

CNPq, IQ-UnB and Universidade Católica Dom Bosco - UCDB, MS.

\section{REFERENCES}

${ }^{1}$ Hardman, J. G.; Limbird, L. E.; Molinoff, P. B.; Ruddon, R. W.; Gilman, A G. Goodman: \& Gilman - As Bases Farmacológicas da Terapêutica, $9^{\mathrm{a}}$ ed. McGraw-Hill: México, 1996.

${ }^{2}$ Oliveira, S. M.; Silva, J. B. P.; Hernandes, M. Z.; Lima, M. C. A.; Galdino, S. L.; Pitta, I. R.; Quím. Nova 2008, 31, 614.

${ }^{3}$ Aspesi, G. H. Síntese de derivados barbituratos e tiobarbituratos de tamanho médio e macrocíclico via translactonização interna. PhD thesis,

Universidade de Brasília - UnB, 2006, pp 356.

${ }_{5}^{4}$ Peng, G. W.; Marquez, V. E.; Driscoll, J. S. J. Med. Chem. 1975, 18, 846.

${ }^{5}$ Kolb, H. C.; Finn, M. G.; Sharpless, K. B.; Angew. Chem. Int. Ed. 2001, 40, 2004.

${ }^{6}$ Aoyama, T.; Sonoda, N.; Yamauchi, K. T.; Anzai, M.; Ando, A.; Shioiri, T.; Synlett 1998, 35

Bauer, H.; Paronetto, F; Burns, W.; Einheber, A.; J. Exp. Med. 1966, 123, 1013 